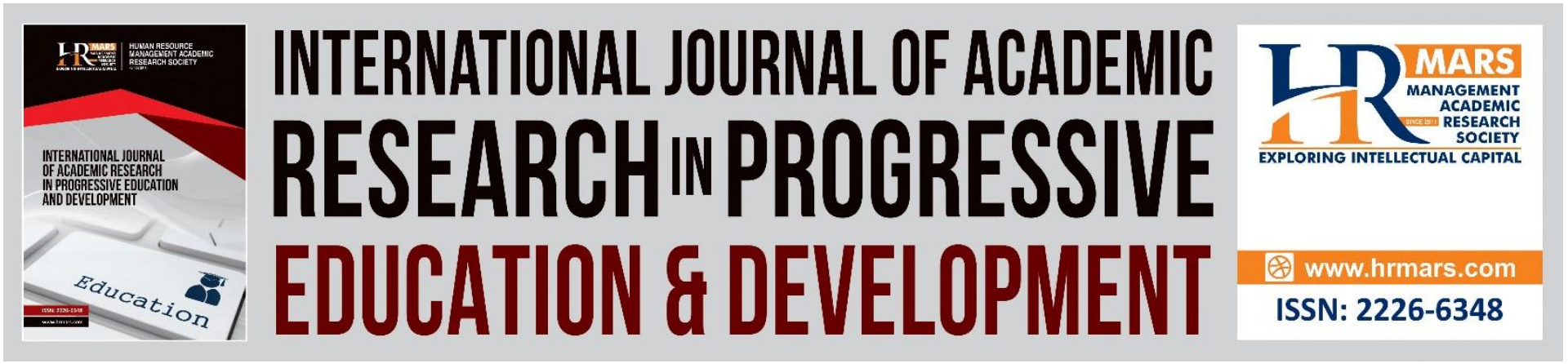

\title{
Fun Learning Through the Integration of Music and Arabic Language Lessons: A Review of Literatures
}

\section{Zaharul Lailiddin Saidon, Mohd Fahrur Rozi Bin Ismail, Mohd Nizam Nasrifan}

To Link this Article: http://dx.doi.org/10.6007/IJARPED/v10-i3/10905

DOI:10.6007/IJARPED/v10-i3/10905

Received: 08 June 2021, Revised: 12 July 2021, Accepted: 30 July 2021

Published Online: 24 August 2021

In-Text Citation: (Saidon et al., 2021)

To Cite this Article: Saidon, Z. L., Ismail, M. F. R. Bin, \& Nasrifan, M. N. (2021). Fun Learning Through the Integration of Music and Arabic Language Lessons: A Review of Literatures. International Journal of Academic Research in Progressive Education and Development, 10(3), 725-738.

Copyright: (C) 2021 The Author(s)

Published by Human Resource Management Academic Research Society (www.hrmars.com)

This article is published under the Creative Commons Attribution (CC BY 4.0) license. Anyone may reproduce, distribute, translate and create derivative works of this article (for both commercial and non-commercial purposes), subject to full attribution to the original publication and authors. The full terms of this license may be seen at: http://creativecommons.org/licences/by/4.0/legalcode

Vol. 10(3) 2021, Pg. 725 - 738

Full Terms \& Conditions of access and use can be found at http://hrmars.com/index.php/pages/detail/publication-ethics 


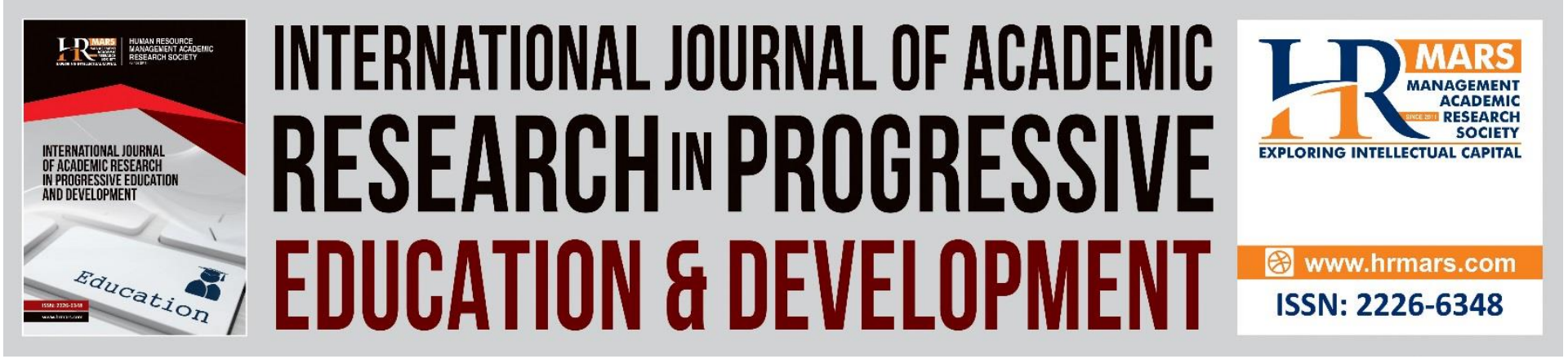

\title{
Fun Learning Through the Integration of Music and Arabic Language Lessons: A Review of Literatures
}

\author{
Zaharul Lailiddin Saidon, Mohd Fahrur Rozi Bin Ismail, Mohd \\ Nizam Nasrifan \\ Universiti Pendidikan Sultan Idris, 35900 Tanjung Malim, Perak, Malaysia
}

\begin{abstract}
The challenge of $21^{\text {st }}$ century education demands teachers to be creative in diversifying their teaching approaches in order to engage with the students and consequently achieve better learning outcomes in their respective classrooms. One of the teaching approaches that needs to be highlighted is fun learning through the integration of music lessons with the teaching of other subjects in school. This paper is focused on the analysis of related literatures related to the application of fun learning through the integration of music lessons with other subjects in the classroom. Critical analysis was conducted on past studies, particularly journal articles retrieved from several databases especially the Google Scholar. The result of the analysis showed the positive effects of using music and singing in the teaching and learning in the classroom especially in improving students understanding and mastery of the subject content as well as in improving students long-term memory. Meanwhile the survey on the aspect of gap showed that there were only a few studies conducted on the fun learning approach especially related to the application of music and singing in the Arabic language lessons. It was concluded that there is a strong justification for the need to conduct a study that focuses on the development of a module on fun learning through the integration of Music and Arabic language lessons for the Malaysian primary schools.
\end{abstract}

Keywords: Arabic Language Teaching and Learning, Fun Learning, Integration of School Subjects, Music Education, Music Teaching \& Learning

\section{Introduction}

Education has constantly undergo changes in facing the challenges of 21st Century living. In the context of education in Malaysia, the transformation from Integrated Curriculum for Primary Schools (ICPS) to the Standard Curriculum for Primary Schools (SCPS) in the year 2017 was to actualise the vision of the National Philosophy of Education (NPE) that is to provide a balance and comprehensive education for all students. However, the implementation of the reviewed curriculum has been argued in terms of the allocation of hours for the teaching and learning of the arts subjects particularly music. Table 1 below shows the list of subjects and 
DEVELOPMENT

Vol. 10, No. 3, 2021, E-ISSN: 2226-6348 @ 2021 HRMARS

their minimum hour per year allocation of time for Level 1 primary schools according the reviewed curriculum.

Table 1

The subjects and annual minimum hour time allocation for Level 1 SCPS (2017 review)

\begin{tabular}{|c|c|c|}
\hline NO. & CORE SUBJECTS & MINIMUM HOUR PER YEAR \\
\hline 1. & Malay Language & 192 \\
\hline 2. & English Language & 160 \\
\hline 3. & Mathematics & 96 \\
\hline 4. & Islamic Studies / Moral Studies & 96 \\
\hline 5. & Science & 48 \\
\hline 6. & Physical Education and Health Education & 48 \\
\hline 7. & Visual Arts Education & 32 \\
\hline \multirow[t]{2}{*}{8.} & Music Education & 16 \\
\hline & ADDITIONAL SUBJECTS & \\
\hline \multirow[t]{4}{*}{9.} & Arabic Language / National School Chinese Language & \\
\hline & / National School Tamil Language / Ibanese & 48 \\
\hline & Language / Kadazandusun Language / Semai & \\
\hline & Language & \\
\hline \multirow[t]{2}{*}{10.} & Assembly & 16 \\
\hline & Total Hour Per Year & 752 \\
\hline
\end{tabular}

As shown by Table 1, it is obvious that languages especially the Malay Language and English Language are the priority and regarded as the essential subjects. The Malay language is allotted with a minimum of 192 hours while the English language is 160 hours per year. Consequently, this has contributed to the reduction of time allocated for other subjects, especially Music. Under the new curriculum the time for Music was reduced by half that is from 32 minimum hours per annum (60 minutes per week) to only16 minimum hours per annum (30 minutes per week). This has caused a big challenge particularly for the music teachers. With only 30 minutes lesson per week, it is rather challenging for schools to provide quality music education to students (Maizatul, 2018). As a comparison to Finland as one of the best countries in terms of the education system, the implementation of music subject is three hours per week which is equivalent to time allocated for Mathematics under the Malaysian School Curriculum. Given this situation, an alternative approach needs to be undertaken in order to achieve the aim of the Malaysia National Philosophy of Education for a balance and comprehensive education.

\section{Background of The Study}

One of the suitable solutions to the above problem is by encouraging the integration of music teaching and learning with the teaching of other subjects especially in the teaching of languages. In the context of this study, the integration of Music with the Arabic Language teaching and learning is proposed. Under the SCPS (2017 review) annual minimum hour time allocation for Arabic Language subject which is an additional subject (non-core subject) that exceeds by three times as compared to the Music subject. We believe that the integration of music lessons and Arabic language lessons can be implemented according to the fun learning 
DEVELOPMENT

Vol. 10, No. 3, 2021, E-ISSN: 2226-6348 @ 2021 HRMARS

approach in order to successfully achieve the standard learning outcomes outlined for both subjects at the same time.

In the attempt of making education more interesting especially for school children, the Ministry of Education Malaysia has proposed various methods that teachers can implement in their teaching involving the fun learning approach. Among the fun learning elements that are widely applied is the use of music and singing. Hence an empirical study needs to be carried out in order to further explore and systematically investigate this initial idea as shown by figure 1 below.

Figure 1

Fun Learning through the Integration of Music \& Arabic Language Lessons

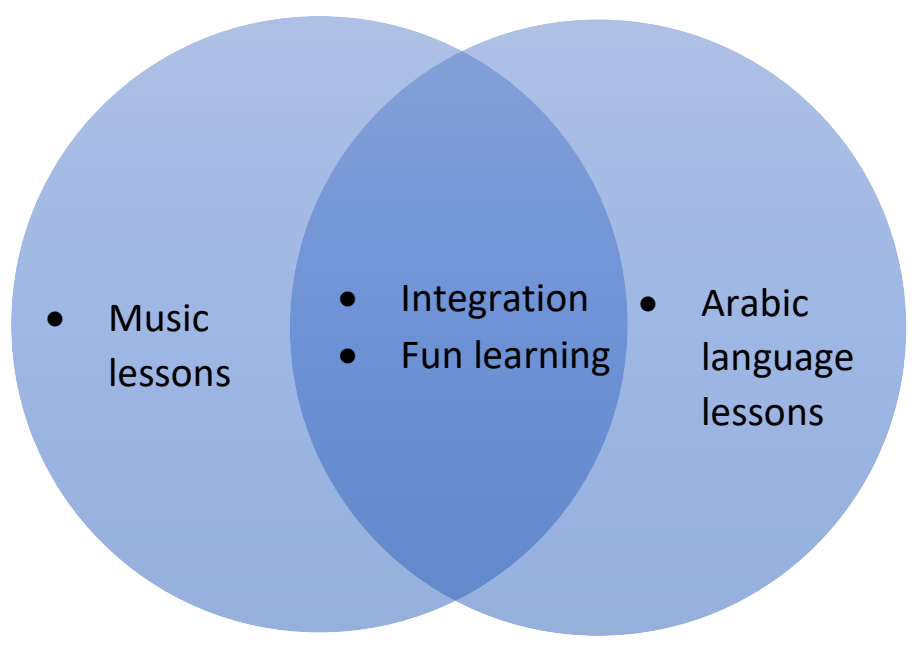

As the initial step to the study, we have carried out a review of related literatures on the integration of music with other subjects and the fun learning approach. A critical analysis was carried out on articles derived from the Google Scholar platform and other databases in order to find out the gaps regarding the fun learning approach especially on the integration of music and singing in Arabic language lessons. As suggested by Ghazali \& Sufean (2021), the critical review was conducted in order to identify the similarities or differences in past studies writings as well as finding the gap in knowledge between the aspects that have yet to be studied. Specifically the objectives of the review of literatures are as follows:

(i) To identify the implementation of fun learning approach using music in the classroom;

(ii) To describe the effects and benefits of integrating the teaching and learning of music with other school subjects especially languages; and

(iii) To identify the need for research that focuses on integrating the teaching and learning of music with the Arabic Language in Malaysian primary schools.

\section{The Review of Related Literatures \\ Fun Learning}

Fun learning is a holistic instructional approach that holds to the basic premise of educating while entertaining (Hanifah et al., 2020). As explained by Ani Omar (2018) teachers create fun environment in their lessons without neglecting the achievement of the teaching and learning objectives (Omar (2018). According to Zanariah and Zamri (2017), the fun learning approach 
will make classrooms to be more interactive and student-centred. Norlela et al. (2021) added that fun learning is a teaching approach that is relaxed, enjoyable and effective. Similarly, Ormilla and Ruhizan (2020) mentioned that using fun learning approach will make students feel more interested in learning. Meanwhile, Rosmadi and Hafizhah (2020) stated that the fun learning approach is a pedagogical method that is relax but in control and enjoyable by connecting the elements of humour, obsession, aesthetics, music and acting in order to attract students to learn. Fun learning is therefore very suitable to be applied in the primary school classrooms (Melvina, 2018). The approach is an effective alternative method to improve reading skills, comprehension and memory (Kornia \& Jamaludin, 2018). Children's literacy skills can be enhanced through the fun learning method (Ramlah et al., 2016).

There are various elements of fun learning approach that teachers can apply in the teaching and learning process. As stated by Mielonen and Peterson (2009), there are several methods used in fun learning approach in improving reading, writing and also to develop children's social skills. Rahman (2015) in his study has applied fun learning through the singing and the use of pantun, a Malaysian traditional poem. Meanwhile, Abdul Rasid (2016) has implemented fun learning through acting and singing in the teaching of topics on the techniques of essay writing in his Malay language lessons. Another study was conducted by Chai and Ng (2020) who used picture books in writing sentences as an element of fun learning in the Mandarin language teaching. Another element that can be applied in fun learning approach is humour according to Hafifi and Musirin (2021). Similarly, Norleyza (2020) mentioned that humour as a significant element in fun learning apart from other elements such as visual arts, games, music and acting. Therefore it can be concluded that fun learning can be implemented in various different ways according to the creativity of teachers through various activities that are appropriate; to educate and entertain students while arousing students' excitement and interest in undergoing a learning process in order to achieve the objectives of a particular lesson.

Music and singing are another elements of the fun learning widely used by teachers in the classroom. As stated by Mahzan \& Ching (2017), music is an exciting teaching medium that can help teachers in the learning process. Similarly, Awang (2021) claimed that singing is one of the elements of fun learning that is preferred by students which can increase students' interest and excitement in learning. Norhasyimah et al. (2018) added that the singing method brings a highly positive effect as students are more active in the learning process. A study undertaken by Ainul (2016) also shows that singing techniques can attract students' attention and interest, thus creating a more active learning in the classroom. Musical activities have a massive influence on children's emotional development (Albaree et al., 2019). Musical elements in learning enhance positive mood among the primary school students (Kamarul \& Mazlan, 2019). The use of songs and music in learning increases the motivation and spirit of the students (Matiin, 2017). Conclusively, results of previous studies clearly show that the use of music and singing as fun learning elements have positive effect towards students motivation in the learning process.

\section{Integration of Music and Singing in the Teaching and Learning of other Subjects}

Music makes daily life and learning more interesting providing methods to develop creativity and contribute to self -expression as well as enrich life, enhance cultural and heritage understanding, foster discipline, commitment and most importantly, it is a source of joy (Elliott and Silverman, 2015). In education, the purpose and objective of fun learning is to 
introduce the basic knowledge of music and build the potential of students to become creative individuals who will appreciate and enjoy music intellectually because music is a valuable asset along with other core subjects such as language, mathematics and science that contribute to the general goals of education (Foong, 2020). Review of literatures showed that there were numerous studies conducted by researchers in Malaysia on the effects of integrating music and singing in the teaching and learning of other subjects throughout the implementation of ICPS until SCPS. In Table 2 we provide the list of studies to show the diverse subjects and effects of integrating music and singing in the classroom. Apart from the integration with subjects like Mathematics, Islamic Studies, Design and Technology, Living Skills, and Physical Education, past studies by researchers in Malaysia have covered the teaching and learning of several languages.

Results of these past studies in Malaysia showed the effects and benefits of integrating element of music and singing in the classroom. Azli and Abu Bakar (2013) claimed that the results of their study has shown that the use of music in learning can enhance the intelligence, cognitive and linguistic development of the children. Meanwhile, the findings of a study undertaken by Azhar and Mazlan (2019) has showed that children's involvement in musical activities can enhance their physical, linguistic, emotional, social, and mental development. In addition singing activities are very suitable to be applied in learning as it is highly effective in strengthening students' memory according to Mok and Lee (1989). Meanwhile Hisyamuddin and Amir (2012), claimed that by integrating music and singing activities in the teaching of other subjects can develop and improve students' social skills. In addition, Rosli \& Omar (2013) has claimed that melody and rhythm as the accompaniment of the singing activity can increase the students' interest and strengthen their memories.

Table 2

The effects of music and singing integration in various subjects.

\begin{tabular}{|c|c|c|c|c|}
\hline No. & $\begin{array}{c}\text { Integration of Music } \\
\text { and Singing in } \\
\text { Subject }\end{array}$ & Scholar & & $\begin{array}{l}\text { Effects of Integration of } \\
\text { Music and Singing }\end{array}$ \\
\hline \multirow[t]{3}{*}{1.} & Malay Language & $\begin{array}{c}\text { Haron A.R et al. } \\
\text { (2015) }\end{array}$ & $>$ & $\begin{array}{l}\text { Improves students' } \\
\text { learning mastery. }\end{array}$ \\
\hline & & Jamian A.R (2016) & $>$ & $\begin{array}{l}\text { The acting element is } \\
\text { more suitable to be } \\
\text { implemented than the } \\
\text { singing element in the } \\
\text { achievement of essay } \\
\text { writing. However, acting } \\
\text { requires a longer time to } \\
\text { implement. }\end{array}$ \\
\hline & & $\begin{array}{l}\text { Melvina and Norazah } \\
\text { (2021) }\end{array}$ & $>$ & $\begin{array}{l}\text { Students are active and } \\
\text { enthusiastic in learning. }\end{array}$ \\
\hline 2. & English Language & Miranti (2015) & $>$ & $\begin{array}{l}\text { Fun and expands English } \\
\text { language vocabulary }\end{array}$ \\
\hline
\end{tabular}




\begin{tabular}{|c|c|c|c|c|}
\hline & & Pitts, S.E. (2016) & $>$ & $\begin{array}{l}\text { Builds confidence, social } \\
\text { interaction, and } \\
\text { enjoyment in children's } \\
\text { linguistic skills. }\end{array}$ \\
\hline \multirow[t]{3}{*}{3.} & Mathematics & $\begin{array}{l}\text { Zahar and Alfero } \\
\qquad(2016)\end{array}$ & $>$ & $\begin{array}{l}\text { Attract and increases the } \\
\text { students' learning } \\
\text { motivation. }\end{array}$ \\
\hline & & Pantun (2016) & $>$ & $\begin{array}{l}\text { Attract students' interest } \\
\text { in learning. }\end{array}$ \\
\hline & & $\begin{array}{l}\text { Sajastanah et al. } \\
\qquad(2021)\end{array}$ & $>$ & $\begin{array}{l}\text { Exciting and focused } \\
\text { learning, builds up } \\
\text { memory, overcomes } \\
\text { anxiety in learning, and } \\
\text { strengthen the students' } \\
\text { mathematical concepts. }\end{array}$ \\
\hline \multirow[t]{2}{*}{4.} & Islamic Studies & Izzuddin (2011) & $>$ & $\begin{array}{l}\text { Creates excitement and } \\
\text { stimulates the students' } \\
\text { interest. }\end{array}$ \\
\hline & & Halim et al. (2017) & $>$ & $\begin{array}{l}\text { Reading and } \\
\text { pronunciation skills as } \\
\text { well as easy to memorise } \\
\text { facts. }\end{array}$ \\
\hline 5. & Living Skills & Hamisan (2010) & $>$ & $\begin{array}{l}\text { Increases the students' } \\
\text { interest, performance } \\
\text { and readiness in learning. }\end{array}$ \\
\hline 6. & Japanese Language & Alif (2018) & $>$ & $\begin{array}{l}\text { Increases motivation and } \\
\text { interest as well as well as } \\
\text { the mastery of Japanese } \\
\text { language vocabulary. }\end{array}$ \\
\hline 7. & $\begin{array}{l}\text { Design and } \\
\text { Technology }\end{array}$ & Norhasyimah (2018) & $>$ & $\begin{array}{l}\text { Students are very active } \\
\text { and enjoy when the } \\
\text { lessons take place. }\end{array}$ \\
\hline 8. & Physical Education & $\begin{array}{l}\text { Azhar and Mazlan } \\
\text { (2019) }\end{array}$ & $>$ & $\begin{array}{l}\text { Students are } \\
\text { enthusiastic, calm and } \\
\text { happy in every activity } \\
\text { that were carried out. }\end{array}$ \\
\hline
\end{tabular}


There are numerous evidence from a variety of sources suggesting the use of music as an effective and engaging pedagogical tools and could increase students' motivation to learn a foreign language. Among others, Spicher \& Sweeney (2007); Ting (2002); Medina (1993); Lozanov \& Gateva (1989); Rees (1977) have advocated that the integration of music in foreign language lessons could help to provide positive emotions and improvement to learning for students at different ages. Teachers have also reported that music could quickly and effectively create a positive classroom atmosphere, increase the understanding of a foreign or second language and engage students in the linguistic material contained in the song (Jensen, 2000). According to Spicher \& Sweeney (2007), music is a pedagogical tool that is well suited to achieve the goals of modern language teachers. This statement reinforces Murphey's (1990) view that songs and singing can provide pure and challenging second language material, while the repetition of sound and language structure through the use of songs can encourage students to practice second language material outside of the classroom.

Another study on the use of songs and singing in English learning for students was conducted by Ida Vera Sophya (2013) who stated that media plays a role in the teaching and learning process. The findings of her study showed that the used of songs could assist students to understand better and effectively achieved objectives of the lessons. She concluded that the use of songs to be an excellent tool to aid teaching and learning of English. The results of these past studies have indeed strengthened our assumptions o the advantages of integrating music in the teaching and learning of the Arabic language.

\section{Integration of Music and Singing in the Teaching and Learning of Arabic Language}

Despite the many studies conducted on the integration of the teaching of music with languages, we found that there are rather limited number of researches conducted on the integration with Arabic language. Among the few was a study conducted by Febrian et al. (2017) on interactive teaching of Arabic Language at the Arabic Language Centre, Selangor, Malaysia through five strategies namely: (i) Technique of the total usage of Arabic Language in teaching, (ii) Teaching technique through singing (iii) Teaching technique through games (competitions), (iv) Teaching technique through activities and creativity, and (v) Teaching technique using ICT. The second strategy which focus on teaching technique through singing, involved the use of singing, which is one of the elements in fun learning and has been carried out with the production of 25 Arabic songs. The songs were produced using new lyrics based on the learning topic with the accompaniment of original music using MIDI music/karaoke. In terms of the effects, this strategy has produced five positive effects as follows:

(i) The use of singing was well accepted by almost all the students, including students who were shy to the extent where they can carry out well the pronunciation practice of simple expressions;

(ii) The vocabulary was easy to memorise;

(iii) Songs contain words, phrases or words that are repetitive, easy to memorise and enunciate;

(iv) The Arabic Language became close to the students and was no longer a foreign language given that the students sung the songs even outside of the lessons; and

(v) Students find singing as entertaining which help in achieving the learning objectives. 
In a more recent study, Bustam et al. (2021) has developed Arabic language learning materials for first grade in an elementary school based on fun learning approach. The study has employed the Classic Experimental Design which comprised of two groups of students in which one was utilized as a control group, and the other as experimental group. The experimental group received a treatment using the Arabic language learning materials while the control group were taught with the conventional method. The result of the study showed that there was a significant improvement in the test results of students in the experimental class which indicated that the used of textbook and songs were more effective for students in learning the Arabic language. Based on the results of observations and interviews conducted by researchers with students and teachers, the following points were concluded:

(i) More than $50 \%$ of first grade students were able to read and write simple Arabic writing so that it was very supportive of the development of textbooks based on songs;

(ii) Teachers hoped that teaching materials in the textbooks for Arabic learning are interesting and fun and can be used in learning so that the textbook can make it easier for students to follow the learning process;

(iii) Teachers strongly supported textbooks based on songs which contains material and competency test exercises and different songs available in each chapter;

(iv) The school principal encouraged the creativity of teachers in creating learning innovations. This was proven by the existence of various training programs for making learning media for teachers; and

(v) The school principal concerns with the instructional materials used by teachers in managing the learning process in the classroom.

Another study was carried out by Saidon et al (2021) which focus on the development and evaluation of song album as a teaching aid material for Arabic language lessons in Malaysian primary schools. The song album contains nine songs that were developed using the original Arabic language lyrics as outlined in the primary school Year 1 textbook. The results showed that the appropriate characteristics of music arrangement for songs in an album are as follows:

i. Modern musical instruments combined with local and Arabic traditional musical instruments as it will produce a more unique and interesting composition;

ii. The use of various rhythmic styles that combines modern and traditional elements including the Middle Eastern rhythms;

iii. The combination of adult and child singers;

iv. Different tempos with energetic mood; and

v. Taking into consideration the possibilities of combining singing songs with dance and movement activities.

Expert evaluation of the album stated that the songs produced were of good quality in terms of singing and musical arrangement. Meanwhile, the results from the aspect of usability found that all songs in the album were interesting and suitable to be used as teaching material for Year 1 Arabic language lessons in Malaysian primary schools. However, the limitation of this study was that it was focused on the development of the song album as teaching aids and did not investigate on the effect of using the songs in the actual teaching and learning process.

Saidon et al (2021) also raised the issue regarding the large number of Arabic language teachers not having the basic competencies to teach music and singing. Similarly, Bustam et al. (2021) has also raised the same issue regarding Arabic language teachers facing difficulty 
in singing the songs listed in the textbook. They have suggested that in order to carry out fun learning in the classrooms, Arabic language teachers need the support of teaching aids such as the album of songs in Arabic language. Based on the findings of their studies, the production of the song album would make it easier for Arabic language teachers to be more confident in carrying out the fun learning activities in the classroom. With that, the implementation of singing activities using songs in the album can help in making their lessons more exciting and compelling.

\section{Discussion}

Based on the review of literatures including studies conducted in Malaysia since the implementation of ICPS in 1983 until SCPS in 2017, we could conclude that the integration of music and singing in teaching and learning of others subjects have numerous benefits and advantages to students in terms of their physical, emotional, spiritual and intellectual development. This is very much in line with the aspirations and aims of the Malaysia Philosophy of Education which intend to provide a comprehensive and well balanced education. Past studies also has shown the increase in students mastery in learning as the results of applying fun learning elements particularly in terms of stimulating students interest and raising their enthusiasm towards a particular subject.

However, we found that previous studies particularly those conducted in Malaysia were rather limited in scope and aims in the sense that the studies were just focused on the benefits and effects of using music and singing as tools to achieve the objectives and learning outcomes of other subjects. None of the studies have investigated on student's achievement in music knowledge, skills, musical awareness and appreciation based on the learning outcomes outlined in the school music syllabus. While we recognised the advantages of using music and singing in the teaching of other school subjects, we would like to argue that this kind of practice could not be considered as the integration approach in classroom teaching and learning. We agree with Snyder (2001), who defined integration in the curriculum as the integration between subjects which are combined and implemented in a balanced way according to the syllabus. For example, the integration of Arabic language teaching with music requires objectives of both subjects to be achieved rather than simply achieving the learning outcomes of the Arabic language syllabus.

According to Snyder's definition, if the achievement of objectives and the positive effects were aimed only at the Arabic language syllabus, then the approach is more suitable to be defined as merely application rather than integration. Therefore previous researches could only be defined as application of music and singing as fun learning rather than integration of the teaching and learning of two different school subjects. This is because the implementation of integration must be done in a balanced manner with the application of a combination of themes or content between subjects. Nonetheless, we should not deny the positive effects of the application of fun learning through music and singing activities.

Clearly, there is gap in the current body of knowledge regarding the integration of music and other subjects in the real meaning of integration as a teaching and learning approach. Specifically in the context of this article, there is a need to conduct a study on fun learning through the integration of music with the Arabic Language. Even though there were several studies that have been conducted related to the integration of music in various subjects, there is still a lack of studies on the integration of musical teaching with the Arabic Language, specifically involving primary schools in Malaysia. 


\section{Conclusion}

This paper has focused on the analysis of related literatures related to the application of fun learning through the integration of music lessons with other subjects in the classroom. Critical analysis was conducted on past studies, particularly journal articles retrieved from several databases especially the Google Scholar. The result of the analysis showed the positive effects of using music and singing in the teaching and learning in the classroom. Meanwhile the survey on the aspect of gap showed that there were only a few studies conducted on the fun learning approach especially related to the application of music and singing in the Arabic language lessons. Therefore there is a need to conduct studies on fun learning through the integration of music with the Arabic Language specifically at the primary schools level in Malaysia. In addition, our review of literatures also showed that generally Arabic language teachers do not have the basic competencies to teach music and singing. Consequently, this shows that Arabic language teachers need the support such as guide books, modules and teaching aids in order to carry out fun learning effectively in their classrooms.

Education in Malaysia is constantly changing in meeting the development of today's globalisation era. The initiation of the $21^{\text {st }}$ Century Education Program by the Malaysia Ministry of Education proves the determination to improve the standard of education in Malaysia which covers all levels from early childhood education up to the higher education. Among others, fun learning is an activity encouraged to be implemented in lessons to make learning more interesting and effective. Fun learning can be implemented in various different ways according to the creativity of teachers through various activities that are appropriate; to educate and entertain students while arousing students' excitement and interest in undergoing a learning process in order to achieve the objectives of a particular lesson. Music and singing are among the best choice of medium to facilitate fun learning especially in the primary school classrooms. Music and singing as elements of fun learning are widely implemented in various school subjects and has shown positive effects during and after its application in the classroom which include improvement in interest, motivation, enjoyment, memory, composure, performance and students' mastery in learning.

The reduction of time allocation for primary school Music subject from 60 to 30 minutes per week has caused a big challenge for music teachers in Malaysia. Given this situation, the integration of music teaching with Arabic language teaching is an effort towards achieving the aspirations of Malaysian Ministry of Education as outlined in the $21^{\text {st }}$ Century Education Program which encourage teachers to be more creative in exploring new teaching and learning methods. However despite the many previous studies regarding fun learning specifically involving music and singing in various subjects, there is still a lack of study on the integration of music teaching with the Arabic Language in achieving the learning objectives according to the syllabus of both the subjects. Previous researches could only be defined as application of music and singing as fun learning rather than integration of the teaching and learning of two different school subjects in the real sense.

\section{References}

Abdullah, M. A. R., \& Hussin, S. (2018). Penggunaan Lagu dalam Meningkatkan Penguasaan Kosa Kata dalam Kalangan Pelajar Bahasa Jepun di Universiti Putra Malaysia: Usage os Songs in Enhancing Vocabulary Acquisition among Japanese Language Learners in Universiti Putra Malaysia. The Sultan Alauddin Sulaiman Shah Journal (JSASS), 5(2), 279288. 
Abdul, M. A., Ismail, H., Mohamad, I., \& Osman, Z. (2019). Perkembangan emosi kanak-kanak menggunakan kaedah pengajaran berasaskan aktiviti muzik. Jurnal Pendidikan Awal Kanak-Kanak Kebangsaan, 8, 17-23.

Affero, I., \& Kusnun, M. (2016). Penerapan Kaedah Didik Hibur Terhadap Motivasi Belajar Di Kalangan Murid Di Sebuah Sekolah Rendah Daerah Kluang.

Ahmad, N., Othman, S., Sabil, A. M., Mokhtar, M. M., Nawawi, M. A. M., \& Hason, Z. (2021). Pengaruh Didik Hibur dalam Meningkatkan Kesediaan Belajar Kemahiran Membaca Bahasa Melayu Murid Belum Menguasai Tahap Pencapaian Minimum [The Influence Of Edutainment in Enhancing The Learning Readiness of Reading Skills in Malay Language of Low Achieve. Asian Journal of Civilizational Studies (AJOCS), 3(1), 45-57.

Arshad, M., \& Ching, C. S. (2017). Penilaian semula pengajaran dan pembelajaran dalam pembacaan awal. Jurnal Pendidikan Awal Kanak-Kanak Kebangsaan, 6, 79-86.

Beraoh, O. A. A., \& Yasin, R. M. (2020). Penerapan Identiti Nasional dalam Mata Pelajaran Bahasa Melayu Bagi Murid Tahun Enam Sekolah Rendah. Jurnal Dunia Pendidikan, 1(3), 57-64.

Darusalam, G., Hussin, S. (2021). Metodologi Penyelidikan dalam Pendidikan: Amalan dan Analisis Kajian. 3rd ed. Kuala Lumpur: Universiti Malaya.

Febrian, D., Lubis, M. A., Yasim, I. M. M., \& Wahab, N. S. A. (2017). Teknik Pengajaran Bahasa Arab Interaktif Di Pusat Bahasa Arab Negeri Selangor. Asean Comparative Education Research Jounal on Islam and Civilization (ACER-J). eISSN2600-769X, 1(1), 78-93.

Habidin, N. F., Muhamad, U. A., Ong, S. Y. Y., \& Chik, T. W. T. (2021). Pembangunan Penyelidikan dan Inovasi dalam Teknologi, Pendidikan dan Sains Sosial. Kaizentrenovation Sdn Bhd, Tanjung Malim.

Hamzah, N., Omar, R., Ariffin, A., Rubani, S. N. K., \& Subramaniam, T. S. (2018). Penggunaan Kaedah Nyanyian dalam Mata Pelajaran Reka Bentuk dan Teknologi. Online Journal for TVET Practitioners.

Haron, A. R., Badusah, J., \& Mahamod, Z. (2016). Kemahiran Berfikir Aras Tinggi (KBAT) Dalam SALAK DIDIK dengan Elemen Nyanyian dan Elemen Pantun (Higher Order Thinking Skills (HOTS) in SALAK DIDIK Singing and Pantun Elements). Jurnal Pendidikan Bahasa Melayu, 5(1), 53-60.

Hisyamuddin A. R., \& Amir H. S. (2012) Kaedah nyanyian dalam mengatasi masalah miskonsepsi dalam kalangan pelajar tahun tiga dalam topik magnet. Persidangan Kebangsaan Pembangunan dan Pendidikan Lestari. Institut Pendidikan Guru Kampus Tuanku Bainun, Bukit Mertajam, Pulau Pinang.

Koning, I. S., Nasrifan, M. N., Junus, M. N. W., \& Azmi, N. (2021). Integrasi aktiviti muzikal dalam pengajaran dan pembelajaran matematik: Satu kajian literatur. Jurnal Pendidikan Bitara UPSI, 14, 92-102. https://doi.org/10.37134/bitara.vol14.sp.10.2021.

Ismail, M. J. B., Yusuf, R. B., \& Chiat, L. F. (2018). Aktiviti muzikal yang sesuai dijalankan semasa proses pengajaran dan pembelajaran muzik murid-murid pintar dan berbakat di Malaysia. Malaysian Journal of Social Sciences and Humanities (MJSSH), 3(5), 30-40.

Jamian, A. R., Razali, N. N., \& Othman, S. (2016). Pengaplikasian Teknik Didik Hibur Meningkatkan Pencapaian Penulisan Karangan Bahasa Melayu. Malaysian Journal of Education (0126-6020), 41(1). 
Jantan, R. B., Resad, N. A. B., \& Mohd, S. F. A. Z. B. (2016). Aktiviti didik hibur dalam kalangan guru prasekolah di daerah Gombak. Jurnal Pendidikan Awal Kanak-kanak Kebangsaan, 5, 19-29.

Kamarudin, K. A., \& Ismail, M. (2019). Kesan muzik semasa aktiviti kegiatan jasmani terhadap mood murid-murid sekolah rendah. Malaysian Journal of Movement, Health \& Exercise, 8(1).

Kassim, A. M. (2017). Kesan 'Mozart'Dan Teknik PCRPP Dalam Pembelajaran Penulisan Karangan Naratif. PENDETA: Journal of Malay Language, Education and Literature, 8, 110.

Ching, M. C. H., \& Nordin, N. M. (2021). Penilaian Terhadap Permainan Interaktif Didik Hibur dalam Pembelajaran Tatabahasa Bahasa Melayu Sekolah Rendah. JuKu: Jurnal Kurikulum \& Pengajaran Asia Pasifik, 9(2), 18-25.

Mohamed, A. H. B. (2016). Teknik Nyanyian Dan Permainan Karom Membantu Murid Tahun Satu Mengenali Kedudukan Dan Bilangan Titik Huruf Jim, Cha, Ha Dan Kha Dengan Betul (Doctoral dissertation, Universiti Sains Islam malaysia).

Miranti, I., \& Engliana, F. S. H. (2015). Penggunaan Media Lagu Anak-Anak dalam Mengembangkan Kemampuan Kosakata Bahasa Inggris Siswa di Paud. Jurnal Ilmiah Kependidikan, 2(2), 167-173.

Mok, S. S., dan Lee S. M. (1989). Latihan mengajar untuk maktab perguruan. Kumpulan Budiman Sdn. Bhd. Kuala Lumpur.

Pantun, R. (2017). Penggunaan teknik nyanyian dalam meningkatkan kefahaman murid tahun dua dalam topik pembundaran. Proceedings of the ICECRS, 1(1).

Pitts, S. E. (2016). Music, language and learning: Investigating the impact of a music workshop project in four English early years settings. International Journal of Education \& the Arts, 17(20).

Razab, H. A., \& Sharaai, A. H. (2012). Kaedah Nyanyian dalam Mengatasi Masalah Miskonsepsi dalam Kalangan Murid Tahun 3 dalam Topik Magnet.

Rosli, M. F., dan Omar, B. (2013). Penggunaan teknik nyanyian dan mnemonik dalam meningkatkan penguasaan kata sendi nama dari pelajar tahun tiga. Kajian Tindakan PISMP 2013, 2(7).

Rusmin, M. I. A. B., \& Ismail, K. D. R. (2011). Keberkesanan Nyanyian Melodi Ria Untuk Meningkatkan Kemahiran Mengingat Nama 10 Malaikat Bagi Murid Tahun 2 Delima Sk Kampung Gemuroh. Kuala Terengganu. Institut Pendidikan Guru Kampus Dato'Razali Ismail.

Saidon, Z., Nasrifan, M., Al Muhsin, M., \& Ismail, M. (2021). The Development and Evaluation of a Song Album as an Instructional Material for the Teaching and Learning of Basic Arabic Language in Malaysian Primary Schools. Turkish Journal of Computer and Mathematics Education (TURCOMAT), 12(3), pp.370-380.

Salim, H., \& Saud, M. S. (2010). Penggunaan Muzik Dalam Pembelajaran Dan Pengajaran kerja Amali Kemahiran Hidup Sekolah Rendah (Doctoral dissertation, Universiti Teknologi Malaysia).

Wahab, Z., \& Mahamod, Z. (2017). Pengetahuan, Kemahiran Pelaksanaan dan Sikap Guru Bahasa Melayu Sekolah Rendah Terhadap Pendekatan Didik Hibur. Fakulti Pendidikan, Universiti Kebangsaan Malaysia.

Walker, T. D. (2017). Teach like Finland: 33 simple strategies for joyful classrooms. WW Norton \& Company. 
INTERNATIONAL JOURNAL OF ACADEMIC RESEARCH IN PROGRESSIVE EDUCATION AND

DEVELOPMENT

Vol. 10, No. 3, 2021, E-ISSN: 2226-6348 @ 2021 HRMARS

Zainuddin, M. S. (2018). Kesan pembelajaran koperatif Teams-Games-Tournament (TGT) terhadap pencapaian murid tahun 4 dalam mengimprovisasi idea muzik (Doctoral dissertation, Universiti Pendidikan Sultan Idris). 